Research, part of a Special Feature on Nudging Evolution? Critical Exploration of the Potential and Limitations of the Concept of Institutional Fit for the Study and Adaptive Management of Social-Ecological Systems

\title{
How fit turns into misfit and back: Institutional Transformations of Pastoral Commons in African Floodplains
}

\author{
Tobias Haller $^{1}$, Gilbert Fokou $^{2}$, Gimbage Mbeyale $^{3}$ and $^{\text {Patrick Meroka }}{ }^{4}$
}

\begin{abstract}
We enlarge the notion of institutional fit using theoretical approaches from New Institutionalism, including rational choice and strategic action, political ecology and constructivist approaches. These approaches are combined with ecological approaches (system and evolutionary ecology) focusing on feedback loops and change. We offer results drawn from a comparison of fit and misfit cases of institutional change in pastoral commons in four African floodplain contexts (Zambia, Cameroon, Tanzania (two cases). Cases of precolonial fit and misfit in the postcolonial past, as well as a case of institutional fit in the postcolonial phase, highlight important features, specifically, flexible institutions, leadership, and mutual economic benefit under specific relations of bargaining power of actors. We argue that only by combining otherwise conflicting approaches can we come to understand why institutional fit develops into misfit and back again.
\end{abstract}

Key Words: African floodplains; governance; institutional change; institutional fit; New Institutionalism; pastoral commons

\section{INTRODUCTION}

In the debate on sustainable use of natural resources, Hardin's (1968) scenario of a pasture open to all is one of the key metaphors common to natural and social sciences. The overall theoretical assumption is that human participants are trapped in a tragedy of the commons. The critique of Hardin has led to the now highly influential scholarly discourse on the study of the commons. Here, instead of Hardin's trap, it is assumed that humans are indeed able to both organize themselves and craft institutions for sustainable use of common pool resources such as pastures, wildlife, fisheries, and forests, among others (Berkes 1989, Bromley and Cernea 1989, McCabe 1990, Ostrom 1990, 2005, Agrawal 2003, Haller 2007b, Homewood 2008, Ostrom et al. 2002).

However, there is another position contrary to Hardin's (1968) proposed by Young's concept of institutional fit with its attention focused on how institutions relate to ecosystem features: fit acknowledges the capacity that local actors have, in developing institutions, to cope successfully especially with environmental problems that they wish to address. This is in stark contrast to what Hardin evokes, with his notion of a tragedy of the commons: for him institutional fit, as a result of collective action of resource users, is impossible, due to the economic and strategic motivations of rational actors, and this impossibility is especially well illustrated by the mismanagement of pastoral common pool resources. Young presumes, instead, that such matching is possible and that 'fitting' institutions can be built and must be judged accordingly, by paying attention to empirical differences between environmental problems in different contexts. However, as a precondition, these problems must be recognized by local actors and there must be provision for the possibility of crafting regulations, based on "agreement of appropriate structure of rights, rules, and decisions making procedures" (Young 2008:21).

Accordingly, Young's orientation focuses on how specific ecosystem properties and institutional arrangements fit in specific social ecological constellations. We focus on pastures as a specific common pool resource, managed by common property systems, in order to discuss this point. Young's notion of fit asks for a prioritization of important ecosystem features and we deal with a specific type of ecosystems, floodplains in African drylands and the way local pastoral groups have adapted to these culturally modified landscapes. We therefore wish to emphasize that the common pool resource we are focusing on displays an anthropogenic character, a notion we will outline in more detail below. Furthermore, in line with Young's position we argue on the one hand that relationships between rainfall, floods, landscape quality (patchiness), and availability of pasture, as well as sickness, are all ecological features to which pastoral nomads have to adapt (see also Homewood 2008) and, on the other, that elements of human adaptation to the past and present political environment should be included as drivers of fit, such as interactions between members within a group and with other groups (peasants, fishermen, and other pastoralists). This is particularly relevant, in our case, with regard to competition and coordination of resource use, land rights, and land use issues. This expanded view of the concept of fit argues that fit should focus not only on adaptation to natural but also to culturally modified ecosystems, that have coevolved in the interaction with users groups directly and that the results of adaptation to political and institutional interactions between user groups should be included as well. To put it differently: pastoralists have to

\footnotetext{
${ }^{1}$ University of Bern, Institute of Social Anthropology, ${ }^{2}$ NCCR North-South, University of Bern, Switzerland University of Yaounde, Cameroon, ${ }^{3}$ Soikoine University, Tanzania, ${ }^{4}$ University of Zurich, Switzerland
} 
adapt to a cultural landscape reproduced by them and used on the basis of locally developed institutions that are binding both within and between groups. Therefore fit should be concerned not only with the natural conditions but also with the anthropogenic landscape of the ecosystem and the institutions that groups of humans use to help them shape it. This echoes what Farrell (2007) has labeled "recursive coevolution".

Based on this view we focus on external changes that have, since colonial times up until today, shaped the political environment in African pastoral lands: Central features in this context are a) a critique of the colonial view that present landscapes are "pure nature" and not cultural landscape ecosystems and b) the involvement of the colonial state, claiming ownership of "pure nature" (see Neumann 1998, Haller 2007b, Haller and Galvin 2008). This claim of state ownership logically leads to plural institutions with new boundaries, legal frames for tenure systems, taxation, and state governance. Pastoralists therefore face massively transformed arenas, in which they are forced to operate, which strongly influences the ways in which natural resources are seen and perceived by them and by the other actors involved.

These elements are discussed in detail in a New Institutionalist framework concerning the subject (see Ensminger 1992, 1998, Haller 2010a,b, 2013) and influence our approach. The approach used here should not be misinterpreted as a purely rational choice concept, as discussed in New Institutional Economics (Williamson 1975), but as a concept derived from and inspired by economic anthropology and political ecology that focuses on issues of power. We propose that both elements of adaptation - to the natural/cultural landscape ecosystem and to the political environment - and that their interplay is crucial for understanding the concept of fit. We indicate along the way and at the close, avenues for developing the concept further, along these lines. Adaptation to a risk of climate variability, in terms of rainfall, inundation and sickness, can be met with more flexible rules for access to pasture, with reserves for dry season and with reciprocal access to other territories and livestock sharing arrangements. However, adaptation to a changing political environment carries with it much more insecurity that is important for understanding strategic action: In this context the role of institutions, as rules of the game for coordination and information provision, is particularly important (Ensminger 1992, Haller 2010a,b). Institutional fit as a concept then needs to incorporate discussion of the relationship between adaptation to the political environment and to the cultural landscape ecosystem.

This requires, particularly in the context of African pastoralism, that attention is given to historic changes and to the ways in which different actors try to access resources and to how they use or are constrained by different institutional settings. While the relationship between structural settings and common property institutions has been widely discussed (see Ostrom 1990, 2005, Ostrom et al 2002), there is a need, especially in our study context to also incorporate issues of power, since the political environment shapes the way resources are perceived in the context of use and the way that this transforms incentives for, or constraints upon, use (Haller 2010c). Mobility is a case in point: in order to adapt to an uneven spread of different grass-cover in a floodplain pasture, mobility is crucial if overuse of one section of pasture is to be avoided. However, if, for reasons of asymmetries of power, this mobility is not possible, or is economically not beneficial or not feasible, adaptation to the political environment, and/ or to markets might be of higher importance for actors than adaptation to the special characteristics of the ecosystem.

In order to show such processes at work it is necessary to conduct a qualitative comparison of findings, which address the same resource base, with similar ecosystems (latter point Ostrom personal communication): to understand the conditions under which fit institutions can evolve and how actors go about creating them. As Becker and Ostrom (1995) have pointed out, some time ago, ecosystems matter in this type of analysis and should be ideally similar if a comparison is to be successful. In addition, general methodology of social and cultural science calls for comparison of similar human systems and states, in the event that we will have to deal with the issue of institutional change being driven by a variety of factors. Such a process, which we apply here to a selection of pastoralist case studies from across Africa, should, we believe, lead to more information on what fit institutions could mean in multiple concrete settings with similar ecosystems, helping to reveal where these factors are crucial for understanding why certain institutions represent a fit or a misfit.

\section{INSTITUTIONALIST ANALYSIS AND COMPARATIVE APPROACH}

Among those in anthropology who have opted for such study, Jean Ensminger is working on the topic of institutional changes among the Orma pastoralists in Kenya (Ensminger 1992, 1998). She indicates that the process driving enclosure of a pastoral commons and the conflicts that make distribution of resources difficult goes back to external factors such as markets, environment, technological change, and demographic change, which influence changes in the relative prices for goods and services. As these prices change - for example for cattle and pasture, as compared to other goods - changes in power among different actors occur. Actors with more bargaining power will shape the institutional setting to function such that they profit the most. However, such shifts have to be legitimized, which is done by specific sets of ideologies. Institutions shaped in this way will influence distribution and finally the outcome of use and will therefore have a huge impact on the ecological condition of a resource such as a pasture. Ensminger (1992), following North (1990), argues that it is not the most effective institutions that emerge 
from this process but the ones fitting the needs and wishes of the more powerful, often with negative outcomes for the resource itself, such as overstocking, soil erosion, reduction of grass cover and quality, and also leading to human conflicts - situations of institutional misfit which are also analyzed by scholars of political ecology (Zimmerer and Basset 2003, Haller 2007b for an overview).

The basic question, which we want to address here, is related to this last point. We aim to link discussion of ecological processes, including analysis of fit, which is understood as institutional arrangements that address environmental problems (Young 2008), with the discussion on what constitutes appropriate institutions and how their change is driven by power issues. Our guiding question is: under which cultural landscape and political conditions are humans able to craft institutions, in a complex context, that fit the anthropogenic ecosystem setting within which they are living and why do such institutions erode? These two questions need to be addressed first, before one can address the policy related question: under which condition can such systems be revitalized or emerge under new contexts (see also Haller $2010 c)$ ?

We will offer a range of answers to these first two questions in the following pages, based theoretically on an approach that focuses on the study of institutions. To do this, we link rational choice, political ecological, and postmodern theories of power together, in order to develop an analysis of nature-culture interactions, which we apply for four social-anthropological case studies concerning African floodplain ecosystems ranging from precolonial, through to colonial and on to postcolonial periods: two located in Tanzania, one in Cameroon and one in Zambia (Fig. 1). While Cameroon is located on the other side of the Congo Basin from the first three studies, the cases are both ecologically and culturally broadly comparable (further details on these and other similar cases can be found within the larger comparative study reported in Haller 2010c).

\section{SUSTAINABLE USE, INSTITUTIONAL CHANGE, AND FIT TO NATURAL AND SOCIAL SYSTEMS}

There is a long tradition in economic anthropology and related fields, of proposing to link institutions - especially property rights systems - to sustainable use of natural resources such as pastures (McCabe 1990, Ostrom 1990, Ensminger 1992, Platteau 2000, Homewood 2008). First, because of two characteristics assigned to these resources under a conventional economic view: (1) they are common pool resources for which exclusion of other users is difficult (but not impossible for groups) and (2) the cumulative use of the resource is subtractable (i.e., use by one person makes use by another impossible - at least in the short run). Such resources can be managed under different property regimes but generally studies indicate that the best way to manage these resources is under a combination of property rights that include a largish set of people with shared property rights and some kind of common property agreements. One of the main reasons for this is that in this way transactions costs can be reduced, since common property regimes provide a general coordination framework for information sharing, monitoring, and sanctioning (Becker and Ostrom 1995, McKean 2000, Haller 2010a, 2013).

Fig. 1. Map: Location of studied floodplains

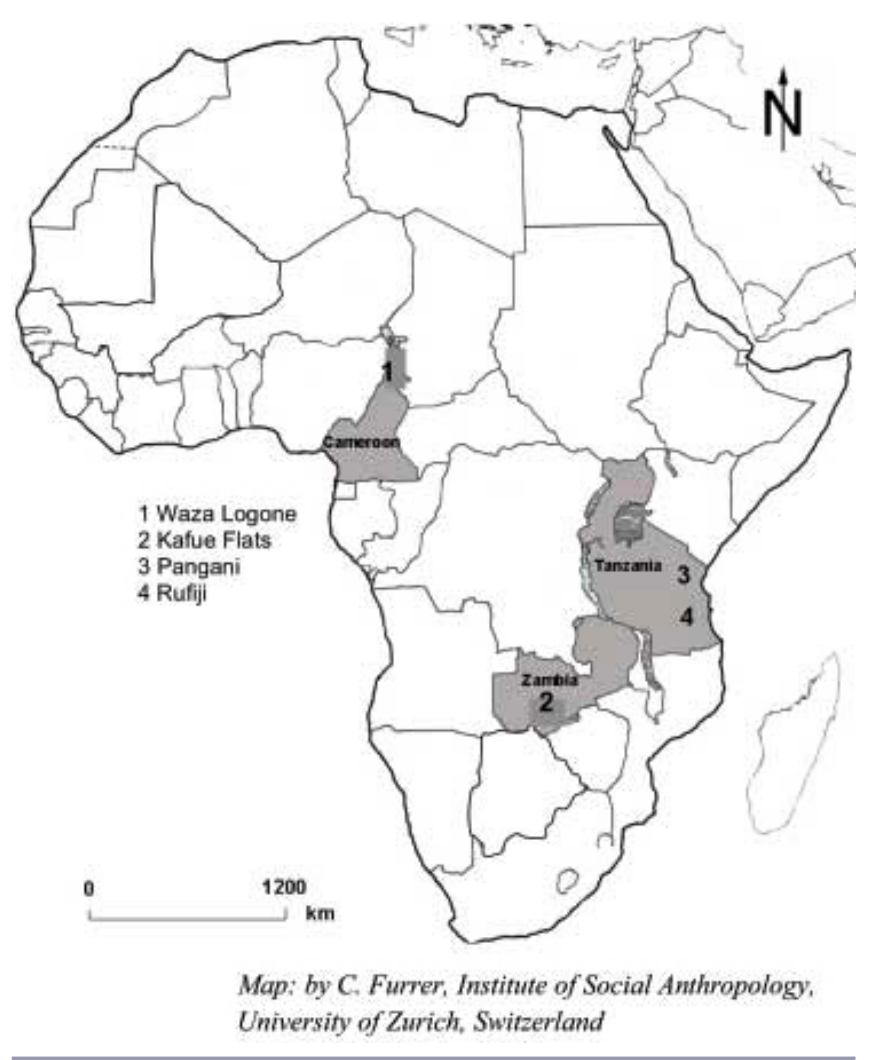

Of major importance, and as outlined in the introduction, more and more scholars dealing with the notion of nature are coming to support the proposition outlined above that, as Roy Ellen (1982) puts it, "pure nature does not exist" (see also Neumann 1998, Brockington and Homewood 2001, Haller 2007a, $2010 c, 2013$ for an overview on this topic). Here, in keeping with that position, we adhere to the basic argument that what we see as natural resources and ecosystems are more or less strongly influenced cultural landscapes, shaped by local resources users and their way of coordinating resource use. This means that one cannot separate the institutional context from the ecosystem context: these are interlinked or to put in other words, they have coevolved and formed the ecosystem in place (Farrell 2007).

This means that institutional fit (see Young 2008) has to be understood as embedded within specific social ecological 
contexts, in the cases we present here special features of that context include: (i) the precolonial pastoral societies we studied have come to use rights agreements of a temporal nature, fitting with the floodplain cultural landscape and ecosystem dynamics of their context, shifting with seasonal floods, which regulate and coordinate land use, (ii) use is regulated not only among pastoralists themselves but also between different ethnic groups and among different resource users (fishermen, peasants, and pastoralists).

Here we see the concept of fit linked to the way traditional institutional agreements, which are often common property arrangements, have been reached: these agreements are not just about resource use but also about property shared rights, territoriality, and membership, and about timing and coordination or diverse activities in a complex and seasonally changing cultural landscape. In these landscapes, fitting institutions, following Young's definition, must afford adaptation to risks associated with patterns of inundation and of availability of pasture and grass quality that are not completely predictable. Therefore, a key feature of fit for these institutions is that boundaries for the management of floodplain resources exist but are permeable, allowing for flexibility, and can be adapted to variability in the seasonal changes of flood and receding waters, and in the human induced changes to the landscape. While the floods were not human made when these institutions were first developed, the composition of vegetation and often also of wild animals found in a floodplain were based, in part, on the way the pastures had been used, including how access to pasture was regulated. Rich pasture in floodplains is to be found after the receding of the floodwaters, and its use frequently has to be coordinated not only within but also between groups. Therefore it is not sufficient to talk only about fit with regard to the cultural landscape. We must also talk about fit with respect to the political environment, including other groups or competing sections within one group. Institutional fit would then refer to arrangements that are designed mitigate coordination problems and manage conflicts under a wide range of possible change situation that might arise due to a roughly known set of flooding patterns.

This is one of the basic results from studying precolonial systems in the mentioned floodplain areas: we find that agreements among pastoral groups and between pastoral groups and other resource users have been worked out because of mutual economic interests and the possibility to benefit from local collective action. An important element in these societies appears to be religion, which seems to be involved in the establishment of monitoring and sanctioning devices, for example. The complexity of this institutional fit, that is, of the institution of religion, to both the natural and the political environment has led to a specific type of cultural landscape, with a specific quality of pasture and can be seen as a proxy for sustainable use. Here it is important to note that these regimes were operating before colonial times, with the discourse of environmental degradation introduced towards the end of colonial and during postcolonial times, often reliant on false reference to these precolonial landscapes (see also Brockington and Homewood 2001).

Ours is not just a constructivist stance, but an empirical point that has implications for how we understand land rights and sustainability claims: Our research presents evidence that precolonial common property regimes created cultural landscapes that were then falsely labeled as natural by the colonial gaze. This gaze is usually taken as a starting point to refer to sustainability. This makes us question the relevance of the conventional property rights discourses used in relation to the study of resource use in these setting, which we propose are is not appropriate. To support this position, we have collected information on ecological studies (see summaries in publications in Haller 2010c such as Beeler and Frei 2010, Fokou 2010, Mbeyale 2010, Meroka 2010, Haller and Merten 2010, Saum 2010) and have consulted archives and assessed local historical ecological knowledge in collaboration with the local groups about and among whom the research was made. The data for each of the cases we discuss can be found in Haller $2010 c$. While there is not room to discuss all these elements here, it is important to note that data on local ecological knowledge is available from local herders, who are able to indicate where pasture has changed, particularly with relation to dominant grass types, in both quality and composition. A major change, since colonization, has been that higher quality grass, from the pastoralists' point of view, for cattle feeding, has been replaced by less valuable grass types: Changing inundation patterns and changing herding patterns have been identified to be the main force and not climate change as measured by changes in rainfall. Inundation (often before dams were built in certain areas) and rainfall variability and associated variability in flooding have always been part of the conditions to which people were trying to adapt (see the discussion on fit above).

Therefore we argue, based on empirical evidence from local and experts views, that there has been a misfit during colonial and postcolonial times, due to increased state intervention, integration into a market economy and the loss of a sense of local ownership of pastoral and of other interlinked resources (fisheries, wildlife etc.) because colonial and postcolonial states have transferred common property areas and their common pool resources to state and private property. This undermines local institutions and makes collective action costly, by increasing transaction costs on the state level and also at the local level, where coordinating institutions are no longer operational. On the other hand, the bargaining power of outside actors and of powerful local actors within the groups has risen and these actors are now able to shape the new institutional setting and with it, the cultural landscape. We understand ideologies of modernity and discourses of 
Table 1. Basic characteristics of the chosen African floodplains

\begin{tabular}{lccc}
\hline \hline Country (Floodplain) & Ethnic groups & $\begin{array}{c}\text { Floodplain } \\
\text { area }\left(\mathrm{km}^{2}\right)\end{array}$ & $\begin{array}{c}\text { Local annual } \\
\text { rainfall (mm) }\end{array}$ \\
\hline Zambia (Kafue Flats) & Ila & 6500 & 800 \\
Cameroon (Waza-Logone) & Kotoko, Mousgum, Arab Choa, & 12,000 & $500-700$ \\
Tanzania 1 (Pangani River Basin) & Fulbe & 1000 & $500-800$ (plains) \\
Tanzania 2 (Rufiji Floodplain) & Pare and Maasai & 10,000 & 3000 (mountains) \\
\end{tabular}

Source: Research team, Hughes and Hughes 1992, Acreman and Hollis 1996, Haller $2010 b$

decentralization and citizenship, which serve as resources of legitimacy, fostering institutional setting that fit their own short term interest, to reflect a misfit that no longer addresses the interests of the pastoralist land user groups or those of the ecosystems that they are using.

We will argue that, in the three of the four cases we present, we have a misfit situation, where precolonial coordination between social and environmental features has been disrupted by the institution of badly enforced or badly maintained state property regimes and laws, leading to situations that are basically open access and to conflicts, with associated negative environmental outcomes. However, in one case we find that the present setting provides a context where new fit institutions are being built: This is due to an interethnic deal, based on mutual economic interests, well established communication, relative freedom from state control for institution crafting, accompanied by the potential for institution backing by the state and good leadership at the local level. This last case, from Tanzania, deals with an agreement set up between some farming Warufiji village communities with immigrant Barabaig pastoralists. The other examples, indicating the misfit, are located in the Pangani River Basin in Tanzania (Pare farmers and Maasai pastoralists), The Waza Logone in Northern Cameroon (Kotoko fishermen, Musgum farmers, and Fulbe, and Arab Choa pastoralists) and the Ila agropastoralists in the Kafue Flats in Zambia.

\section{METHODS}

All these cases were studied under the African Floodplain Wetlands Project (AFWeP) of the University of Zurich and Bern, Switzerland (Including the Institute of Ethnology in Zurich, Institute of Social Anthropology in Bern and the NCCR North-South University of Bern, Switzerland). Eight researchers conducted fieldwork for between 8 and 12 month in 6 floodplain areas between 2002 and 2008, with the same research design being used for all cases, focusing on institutional change in common pool resource use in these areas. Mostly qualitative anthropological methods were used, such as participant observation, during periods of at least 12 months, in specific villages and regional areas. Fieldwork also included open and semistructured interviews, quantitative household questionnaires, and gender separated focus group discussions, as well as the collection of biographies and oral histories. In addition areas have been visited with specialists (botanists, ecologists, veterinary officers). We will present mostly qualitative results, whereas an overview of the research project can be found in Haller 2010c ( Haller 2010a,b, $d$ ). Three of the co-authors (Fokou, Mbeyale, and Meroka) acknowledge support from the Swiss National Competence Centre in Research (NCCR) North-South: Research Partnerships for Mitigating Syndromes of Global Change, cofunded by the Swiss National Science Foundation (SNSF) and the Swiss Agency for Development and Environment (SDC). Haller $2010 c$ was financed for this supervision by the NCCR and for his research in Zambia with a grant from the SNSF.

\section{RESULTS: ECOSYSTEMS AND CASE STUDIES}

\section{Floodplains as cultural landscape and precolonial institutions}

Floodplains are interesting to study, especially in African drylands (see also Woodhouse et al. 2000), because they provide high but often seasonally variable common pool resources, such as fisheries, wildlife, and pasture, as well was water and good soils. The basic ecological process of these plains is driven by seasonal inundation of an area that in our cases is between 3000 (Pangani Floodplain, Tanzania) and $10^{\prime} 000$ km2 (Rufiji River Floodplain, Tanzania). During high floods, stemming from local rains, but in particular from rains in areas of higher altitude, outside the resource area, resources are difficult to spot and are often open access. However, as the waters recede and immediately thereafter, while the water rests in small depressions and on plains, it leaves wet ground which become rich and most suitable for pasture. As indicated by ecologists (Drijver and Marchand 1985, Ellenbroek 1987, Hughes and Hughes 1992) floodplains are a social-natural system because human use influences water composition, composition of herbivores and thereby the quality and composition of grasses, due to selective use for cattle and due to deposits from domesticated animals in the water (Ellenbroek 1987, Haller 2010a). However, it is not only human use but also the regulation of use, by institutions, or by their absence, that has shaped these ecosystems. In the past, institutional designs that involved common property rules 
adapted to the seasonal flooding were dominant. These systems are now under threat because a) the natural systems to which they were tailored are now themselves under threat, due to technological change (large dams and irrigation systems), so that the ecological context itself is being modified, and b) due to neglect or overuse of the common pool resources, which reflects changes in the political environment, such as changed property rights/tenure systems, state regulation of access to pasture and the transformation of space for agriculture (large plantations) or conservation (protected areas) which are now labeled land, water, or green grabbing (see Cotula et al. 2009, Borras and Franco 2010 for examples). We will next illustrate how this process has worked in the four cases listed above and will then conclude with a comparative analysis, considering what types of social-ecological fit we can find. The case studies and their basic features are outlined in Table 1.

\section{Case study one: Kafue Flats, Zambia}

The Kafue Flats are a floodplain of central importance in southern Zambia, located in a semi-arid area with less than $800 \mathrm{~mm}$ annual rainfall. This ecosystem is part of the Zambezi River System, of which the Kafue is a tributary. Inundation patterns lead to the creation of very rich pasture areas that are used by the agro-pastoralist and transhumant Ila, who live in 11 chiefdoms on both sides of the river. A clear figure for the number of Ila-speaking people is difficult to assess, as they are found as the majority in 5 districts that have about 300,000 people.

Research was done in one of these chiefdoms in Namwala District called Nalubamba (territory Mbeza with 27,000 people and a density of $17 \mathrm{p} / \mathrm{km}^{2}$; see Haller and Merten 2010, Haller 2013). These people immigrated to the region in the 1800s and established their villages in the higher areas of the woodlands. A local 'big-man' leader, controlling the pasture areas, helped to organize access rules, which were agreed among all of the Ila living there. Religious justification was central for the control of the pastures, which were linked to ancestral sprits. Ritual activities were important for coordinating the transhumant movement of cattle (called kuwila and kubola), which were owned as the collective property of a large group, to the pastures, where each extended family had a cattle camp with long-term usufruct rights that were secured by giving one calf for the coordination work of this leader. Such coordinated movements became important for two reasons: First, these were the result of steps taken to mitigate conflicts over pasture use in the past and second, organized moves in such groups prevented further conflicts between larger family groups, over access, and helped guard against environmental threats such as wild animal attack (crocodiles, hippopotamus, lions etc.).

This institutional setting called the matanga rule (plural from lutang a meaning cattle camp) helped to organize a sustainable use of the pasture based on clearly defined areas of use and the application of monitoring and sanctioning mechanisms for management and movements. Within the Flats, cattle would then move around and were herded by members of the extended family. However, neighboring groups could get access to the pasturelands through kinship ties and upon request, making use of reciprocal arrangements. This part of the institutional rules helped to ensure flexibility of access, a kind of flexible fix, which is important in a seasonally changing ecosystem (Haller and Merten 2010, Haller 2013).

Today, pastoral areas in this study region are in a crisis and their use is highly contested: This is the result of major environmental and institutional changes, including technological, legal, and economic changes: A major and important technological change was the building of two dams for hydropower production at the end of the 1980s at the Kafue River, one at Kafue Gorge downstream and one at Itezhi-Tezhi upstream. This changed flooding pattern along the Zambezi River System and lead to an increase of bush and woodlands in the pasture areas and the invasion of alien plants such as the mimosa pigra. On the other hand, cattle herds have been greatly reduced, by $50 \%$, since the period between the 1980 s and early 1990s, due to a cattle disease (thyleriosis parva) and are only recovering slowly (during research $70-80 \%$ of the previous stock). Despite the associated reduction in grazing pressure, the pastures now show signs of degradation - such as a lower quality of grasses and soil erosion in some areas indicating that even current use effort might exceed the new carrying capacity of the changed floodplain (Haller and Merten 2010, Haller 2013).

In order to grasp the full complexity of this situation, it is important to look more closely at the institutional setting. In colonial times the British installed chiefs who were not the same people as the traditional big men leaders. In addition the colonial and the postcolonial state claimed property rights over fisheries and wildlife and later on also ownership of some pastoral areas - by installing protected areas reducing the mobility or cattle - undermining local institutions for the management of these commons. Pastoral lands were the last common-pool resources in Zambia to be exposed to changed administration and state property to be transformed into private property, under a land act of 1995 , which allowed the President and the respective local chiefs (whose authority stems from being descendants of a chief installed by the British) to grant leasehold titles for 99 years, in order to create incentives for investments. The political context behind this law has been a neo-liberal shift from the formerly socialist state, originally established under the leadership of Kenneth Kaunda. The new land tenure regime was demanded by the IMF and World Bank in the 1980s and is intended to secure long-term land use planning, in order to stimulate economic investments and economic growth. These changes were 
introduced by the neo-liberal regime of Fredrick Chiluba in the early 1990s. Decentralization and delegation of more power to local chiefs gave them, together with the president of the state, power to decide who received these leasehold titles (Brown 2005, Haller and Merten 2010, Haller 2013).

In the area studied the land act attracted interest among local actors with high bargaining power and among investors with money. For example, one local opposition leader leased titles and tried to get more. He had good relations with the local overseers of the pasture and, according to several informants, was using his influence in order to ask for an annual rent payment from every family using the pasture. This situation was understood as a privatization process by local actors. The local chief, on the other hand, tried to convert the pasture areas with a large-scale irrigation scheme, arguing that in modern times decentralized solutions to hunger problems had to be found and so agricultural production should be pursued as a local solution. He profited from the presence of a hunger crisis that lead the state and foreign donors to support the irrigation project, which meant access to financial resources for this chief.

The whole conflict, which undermined reliance on traditional land use institutions, lead to a practical situation of unregulated and difficult access to the area, creating incentives for clandestine use of the pasture land, leading in turn to further erosion of local institutions. In addition, since regulation of access to the pasture was reduced and relative prices for cattle were high, outsiders (large scale absentee herd owners) used the opportunity to enter the pastureland, sometime simply by occupying land, sometimes by exploiting kinship ties for free access (Haller and Merten 2010, Haller 2013). In addition change in inheritance law, pushed by the state fostered individual ownership of cattle, meant that people tried to have their animals in individual cattle camps, thus increasing pressure on the pasture. From a system theory perspective, which can be useful for studying the dynamics of this problem, the case shows so called positive feedback loops with negative consequences: While the precolonial fit of institutions to ecosystems was based on adaptation to the landscape features and related matters of intra- and inter-group coordination, the new land act has led to a rise in relative prices for land and to conflicts over pastures, making land grabbing by individuals and privatization of access more likely, while at the same time eroding collective management, as external herders try to find ways to use the pasture as an open access resource. In addition people and their animals have become less mobile, remaining in private cattle camps. This process has led to the deterioration of good pasture, which is becoming increasingly scarce and therefore more valuable, triggering more conflict and further facilitating open access use and privatization of access by a few powerful individuals. This case shows the existence of an institutional fit in the precolonial and even during the colonial era in an ethnically homogenous group and its dismantling, during postcolonial times. The next examples deal with the complexity of managing shared use of common pastures among multiple ethnic groups.

\section{Case study two: Waza-Logone Floodplain in Northern Cameroon}

The Waza-Logone is a large floodplain in the border area between Northern Cameroon and Chad, where it enables the creation of rich pastures for different transhumant nomadic groups such as the Arab Choa, Fulbe and others. The area itself is controlled by a fisherman group called Kotoko, who see themselves as the first comers of the area and have been converted to Islam, although their religious life retains many animistic aspects, including rituals for spirits of the water. The Kotoko are organized in hierarchical feudal systems. Field data was gathered between 2003-2006 in areas in Kalkoussam, a village of Kotoko fishermen in the Sultanate of LogoneBrini. The Kotoko fishermen were the first to settle in the area and to devise rules for use of the land and fisheries. Because of the good grass cover after the floods, the area had been used by nomadic pastoralists for dry season grazing for centuries. Legally, the area had been regarded as a common pool resource, managed in a common property system based on the granting of access rights to nomadic pastoral groups by the Kotoko. The nomadic groups could enter into contracts with Kotoko nobles, who acted as overseers of the pasture. A particular office, called ngalway, was responsible for coordinating timing and access to pastures (Moritz et al. 2002, Fokou 2008). This was meant to avoid conflicts between fishermen and pastoralists and to guarantee access for transhumant pastoralists to dry season floodplain reserves. In this way local institutions reduced the transaction costs associated with land and fisheries use and in addition, helped coordinate other economic activities, such as trade of fish and milk and the herding of Kotoko cattle by the nomadic groups. These arrangements are examples of an institutional fit to the politically and environmentally heterogeneous context of the Waza-Logone floodplain, where management of a diverse range of this ecosystem was coordinated and integrated with the pre-existing economic activities (fishing) and religion (animism to legitimize autochthony and notions of ownership and Islam for handling access rights to water and management). It provided clear procedures and actions and presented focal points for coordination and flexible adaptation to change in the ecosystem (Fokou 2008, 2010).

Two major changes have occurred subsequently, putting this local institutional setting in jeopardy: On the one hand, a dam was constructed in 1979, creating a Lake in Maga, for irrigation, which reduced the flood pattern in Waza-Logone, thereby endangering not only the livelihood of pastoralists but also wildlife in the area (Loth 2004). Afterwards a reflooding project was financed by the Dutch government, but the area recovered only slightly and the hydrological problems associated with recovering of the pastures were not 
satisfactory resolved. While it is true that shortage of water contributed substantially to changes in the area, the institutional change to colonial and then postcolonial times is much more pressing. During the French colonial era (1917-1960), a new tax system was instated and the Sultanate was incorporated into administrative system for land and fisheries use management. After the colonial era the Sultanate lost its power and the area was divided into two municipalities, rendering management of the whole floodplain ecosystem much more difficult. In addition, since the 1900s the agropastoral Musgum, whose population far exceeds that of the Kotoko have moved into the floodplains. The Musgum started to question the authority of the Kotoko, making reference to principles of democracy with regard to resource management, especially after the independence of Cameroon and Chad in the 1960s and again, in the 1990s. The decentralization reform in Cameroon in the 1990s was an important aspect of the political context because it removed the legitimacy of the Kotoko as resource owners and reduced their bargaining power, as majority rule for political decision making was applied. Based on the principles of majority rule, state institution put the nomads groups and the Musgum in a dominant position, as compared to the Kotoko, due to their larger populations. Another issue is change in the land tenure system: Since colonial times land in the village was the property of first the colonial and then the postcolonial government. A new land tenure reform in 1972 formalized land ownership by the state and also helped to enlarge a protected areas established in the 1920s (Waza-Logone National Park). With the common property pasture transformed into state property, land became less accessible for nomads, just as the available area for human use was further reduced by expansion of the protected area and by dam construction for irrigated rice cultivation. Pasture therefore became scarce, increasing relative demand and hence prices for both pasture and cattle. In addition, the nomadic community's contract with the Kotoko was undermined by the state, which demanded a general tax from the nomads for use of the pasture areas and access to the floodplain areas. The nomads viewed this tax as a paid contract for free access to the pasture and were no longer interested in collaborating with coordination of land and fisheries use administered by the Kotoko. As a consequence there are now conflicts over the use of pastures that already show signs of degradation. In the village of Kalkussam, for example, pastoralists now arrive much too early, when people are still fishing, creating major conflicts between fishermen and nomads. The state administrators (police etc.) are not helpful in preventing such conflicts nor do their interventions lead to adaptive solutions. On the contrary, each conflict resolution enables these administrators to receive bribes and other type of payments from all sides (fishermen, agro-pastoralists, and nomads). These administrators are, therefore, interested in maintaining conflicts. In this sense the area is facing institutional change from a common property to an open access situation and partially also a situation of temporal privatization, which has negative consequences for the quality of pastoral land. This situation can be understood as a lack of fit, where institutions are actively encouraging unsustainable use of the ecosystems involved. It is the result, as in the first case described above, of positive feedback mechanisms that are opening up access to the pasture and creating a new economic value for the pastoral area. In the context of decentralization and democratization this pushes competition and conflicts, which are, in turn, the basis for further intensive use of the opened areas, providing incentives for ad hoc privatization, which, in turn, further increases conflicts, which have become a source of income for some local people and for administrators.

Case study three: Pangani Basin, Same District Tanzania The third case deals with the Maasai of Tanzania and their mountain neighbors the Pare, in the Pare mountain area adjacent to two floodplains, one related to the main Pangani River, the other to a tributary of the Pangani. The Pare have managed the mountain slopes since precolonial times and only used the floodplain area for small scale rice production. The Maasai pastoralists have traditionally relied on dry season grazing grounds in the two floodplains, during their customary transhumant movements. While some precolonial conflicts occurred, Pare and Maasai mostly tolerated each other in precolonial times, although there were no formal agreements with regard to access to pasture. The Maasai had rules regulating access to the grazing areas and related to coordination between different lineage groups (Mbeyale 2008). Since colonial times the Maasai have lost land to white settlers, first in the 1890s, with further losses in this area associated with establishment of a protected area called Mkomazi Game Reserve by the British colonial powers, which followed the entry of German forces into the area after world War I (Spear 1997). In terms of rangeland management, local Maasai groups had practiced a transhumance system of free movement during the wet season and more regulated access to floodplain wetland pastures in the dry season (Mbeyale 2008 , 2010). Basically, seasonality implied either scarcity or availability of pastures. In periods of abundance, pastoralists moved away from the wetlands (kitivo) to the dry uplands where resources were abundant only during the wet season, while in times of scarcity, they moved toward the rich wetland pasture banks (mlimbiko). These patterns of transhumance provide another example of an institutional fit constellation adapted to life in a floodplain ecosystem.

The misfit constellation we wish to highlight here has its roots in access restrictions associated with the protected area and in institutional changes in land tenure and increased economic interest in the floodplains, following changes in relative prices: The Mkomazi Game Reserve is the most obvious local manifestation of the colonial disempowerment of local nomadic people and indicates the loss of territories needed for 
movement of cattle (see Brockington 2002, Mbeyale and Songorwa 2008). It represents an access restriction, since one part of the floodplain lies within the protected area, from which Maasai where finally expelled in 1988. In addition, institutional misfit was created by colonial and postcolonial forces, by further restricting the Masaai's access to the common pool resource and by reducing their mobility. Already, in colonial times, access to these resources, which were colonial state property, was only partly tolerated. During this period, these resources were already no longer common property, as far as the local user groups were concerned, but were controlled through indirect rule by the colonial government.

After independence, the new Tanzanian government, under Julius Nyerere, introduced the socialist Ujamaa policy under which people were regrouped into villages. Although resources were state property, all citizens were entitled to equal resource access in line with the Ujamaa socialist state ideology of equality. Forests, land, and water were considered open access. At the same time the Pare people moved down to the plains where they started growing rice more intensively, while in the mountain villages they grew coffee, which gave a good revenue due to its high relative prices.

However after the 1980s, when coffee prices collapsed and Structural Adjustment Programmes (SAPs) were implemented in Tanzania, the capacity of the state to manage the resources and to assist the farmers was reduced substantially (Bagachwa and Limbu 1995). Relative prices first for timber and then for rice and for floodplain land in general, were rising, increasing interest in exclusive access to the forests in the mountains and agricultural land in the floodplains. Due to extensive logging, the area started facing the consequences of soil erosion and reduced water supplies coming from the higher protected mountain forests, which act as watersheds for the floodplains. This lowered flooding, while at the same time groups of Pare farmers were moving from the mountains into the floodplains, to use them for agriculture. This brought them into conflict with seasonal pastoral use by the Maasai lineages, who had to come to the floodplain earlier in the year, because of reductions in their dryland pastures resulting from access restriction associated with protected areas (Mbeyale 2008, 2010).

Due to the new context, of reduced land for pasture and increased interest in floodplain lands for agricultural, which led to rising relative prices pressure for land that was previously used by the Maasai and due to plural legal settings associated with the use of this land, contestation in the floodplain is increasing. However, the state of Tanzania does not show much interest in conflict mitigation, which would be an important step toward addressing this institutional misfit. Here we also see a lack of institutional adaptation to recent changes in the rangeland ecosystem.
In this case the character of the misfit again refers to a contrast from precolonial times, where, although the spaces of this river system were not shared, as in the Cameroon case above, separated use was institutionalized in the traditional systems of the Pare and the Masaai, which ensured, for example, that temporal variation in Masaai use of the floodplains did not lead to conflict with the Pare.

However, similarly to the Cameroon case, here we find that lack of fit relates to the loss of traditional systems that clearly coordinated rights for sharing access between ethnic groups to floodplain resources, which are inevitably sometimes plentiful sometimes scare, with a naturally very high variability. Whereas traditional institutions dealt with the need for flexible fit and were able to accommodate variability, the current lack of fit can be understood to stem from flexible adaptations on the part of both the Pare and the Masaai to the new political and institutional setting of fragmented landscapes. Here there are changing relative values and a changing ecosystem; the production of timber in the mountains and irrigated crops in the floodplains, and the expropriation of lands for private and conservation uses, have profoundly changed the cultural landscape.

Finally, the new lands into which farmers are expanding are the previous dry season pastures of Maasai. Once again the Masaai are being pushed from lands crucial for transhumance. As in the previous two cases, this process increases the force of a positive feedback loop, where ever more intensive use of marginal pastoral lands creates ever increasing conflicts (Mbeyale 2010) and continuing deterioration of the ecosystems from which these resources are being drawn (Mbeyale 2010), thereby exacerbating the problem.

\section{Case study four: Rufiji River Floodplain, Southern Tanzania}

In this final case study, use of pasture by the Barabaig, in the Rufiji Floodplain of southern Tanzania is the main focus. This study shows the successful creation of a new institutional fit that resembles the precolonial fit of the other cases and suggests that it may be possible to devise fit institutions for contemporary use of floodplain pasture.

In the Rufiji area the use of pastoral land is rather new. The system employed here indicates how locally negotiated common property arrangements can be drafted when pastoralists and settled peoples share interests. With its 177 $\mathrm{km}$, the Rufiji River is Tanzania's longest river and produces a large floodplain and a delta at the sea. The floodplain has fertile soil for agriculture but also includes extended grasslands, used mainly by wild animals. There are eight different ethnic groups in the Rufiji area, which are collectively known as Warufiji. They share broadly similar cultural traits but differ notably regarding their occupations and can be divided into three ethno-professional groups: 
agriculturalists, fishermen, and hunter-gatherers. However, among them there is no pastoral group. All the Warufiji groups have traditionally been organized by religious leaders (mpindu) and lineage elders (ukoo). The major religion is based on animistic beliefs, including the notion of spirits in the environment and the existence of ancestral spirits that influence daily life and access to resources. The management and distribution of common-pool resources of land, fisheries, and wildlife were traditionally organized through the religious leaders and the resource management structure they specified. Rules of access were determined by membership in a specific group and were granted to other users on the basis of invitations, similar to the arrangements in the Zambian case. A complex system of regulation existed regarded how to respond to changes in the floodplain ecosystem, with specific regulations coming into force during times of high floods and retreating flood waters. These traditional institutions were partly dismantled during the colonial era by German and later by British administrators who advocated conservation of the area (Neumann 1998). In particular, Tanzania's Ujamaa policies (discussed above in the previous case) have led to relocations and to an opening up of access to various commonpool resources in this floodplain. An open access regime prevailed for some time for many of the resource areas studied in the district (Meroka 2006, Haller et al. 2008, Meroka and Haller 2008).

Research for this case study focused on the so-called twin villages that were founded during Ujamaa times in the early 1960s. One of the studied villages, Mbunju-Mvuleni, is closer to the Selous Game Reserve, while the other, Mtanza-Msona is closer to the urban commercial center, Ikwiriri. Because this village is less than $10 \mathrm{~km}$ away from a market, it has attracted more external fishermen to the local Lake Uba, close to the village, which is now completely open access. The situation with regard to pasture in this village setting, however, is very different, as pastures have not been of major interest to local Warufiji people (Meroka 2006, 2010).

Since the 1990s, Barabaig pastoralists who are culturally close to the Maasai in social and political organization, have been moving into the Rufiji Floodplain in search of grazing lands, as they are no longer able to graze their animals in northern regions (see previous case study) and have, like the Maasai of the Pangani River Basin, been pushed farther away from their original territories throughout the colonial and postcolonial periods.

In recent years about 40 Barabaig households have come to the Mtanza-Msona area. Their leaders approached the local Warufiji leaders asking for permission to use the pastures temporarily. Later, they remained to establish their major homesteads in the area. During research done by Meroka in 2003 and 2005 the Barabaig informants claimed that local villagers were increasingly interested in the pastoralists' products, milk and beef. As fish were becoming scarce and game had been limited for several years, the pastoralists offered welcomed protein substitutes and these nomads were increasingly welcomed by local villagers in Mtanza-Msona. As the pastoralists were politically well organized, they approached the village council to negotiate rules for cohabitation and use of pastures, and were well received. All political forces in the village eventually agreed on a new institution in the form of a land use plan enabling a peaceful cohabitation. The land was divided into two major blocks, one for livestock owners and the other for crop farming. This institutional arrangement gave the Barabaig the right to use pastures, while local Warufiji people remained owners of all natural resources including land, according to the Land Act of 1999. This enabled the Warufiji and the Barabaig to revise land-sharing rules and to further adapt them later, in the face of changing conditions in the market and the floodplain ecology.

Two important factors here were the building of mutual trust between the two groups and the absence of negative state involvement in the area. While in the previous Tanzanian case, free entry to the area was fostered by the Ujamaa policy, here new village land regulations, built on top of Ujamaa rules - a kind of nested enterprise as one of Ostrom's design principles (Ostrom 1990) - helped local people maintain control of the village area, which included the pasture. Significantly, this new fit between institutions and ecosystem was based on the use of traditional leadership structures in both communities and was driven by strong economic interest in both groups being served by the new arrangement (Meroka 2010).

\section{COMPARATIVE DISCUSSION}

What can we learn from the comparison of these examples with regard to the fit model? The major findings are compiled in Table 2 which summarizes the cases and indicates four elements of precolonial and now also postcolonial fit:

- Multiple rights of use: In the precolonial settings common proprietorship of land was related to multiple use rights. These rights were based on systems of generalized reciprocity of access, granted on demand and through coordination both within and between groups (see also Sahlins 1972), while, however maintaining the notion of boundaries and membership in distinct groups.

- Role of accountable leadership: Coordination lies in the hands of some leaders - be they a council of elders, big men or traditional administrators - who are managers of the area and who are engaged together with local communities in the process of creating, enforcing and monitoring rules and regulations. Often this leadership is embedded in the religious system, creating a strong legitimacy for the position of authority. At the same time these leaders are accountable to a larger set of individuals in the society. 
- Flexible fit to social-cultural-environmental systems: These leaders are often oriented to coordinate flexible use in a complex and highly changing ecosystem with all its different resources that is constantly being transformed by local users. One important aspect here is that there is no fragmentation of responsibility, such as was observed in state based management systems, where different state departments have responsibility for different lands and land uses, often with limited coordination capacity. In this way transaction costs are reduced and transactions are embedded within cultural and religious belief systems. These systems are also based on rules of reciprocity with other groups, allowing for flexible use of limited resources, when this becomes economically and ecologically important (see above).

- Subsistence oriented: Products from floodplain areas are not treated solely as market goods. Instead there is a focus on their contribution to subsistence production - and also, at times as gifts and for direct exchange (e.g., cattle for marriage or other reasons).

The basic elements for the misfits which then lead to the loss of capability to maintain the cultural landscapes we have observed are then the following:

- State ownership and dismantling of local institutions: As pastoral resources shift more and more into state control, local accountability for ecosystem impacts and local recognition of resource rights diminish. Often specialized local institutions, oriented toward the particular cultural landscape in question, are dismantled and replaced by state regulations.

- State management lowers the likelihood of local adaptation. New acts and resource management schemes are resource specific, sectoral approaches, concerned with fisheries, wildlife, water, land, and agriculture, veterinary services, energy etc. These are neither integrated approaches to multiple use nor are they flexible regarding the complex ecosystem dynamics of floods and retreating flood waters.

- Increase in relative prices for pastoral areas: Control mechanisms of the state and state interest in integrating producers into a market economy changes the demand for and the relative prices of pastoral common pool resource areas, such as pasture and agricultural land, and their products, such as cattle, fish, and wood, which in turn further impact the prices for pasture and cattle. Through these changes both old and new external users, with a market orientation, are attracted to the floodplain, thus eliminating local accountability for use. Tax payments to the state and private purchase of land, for example, undermine the feeling of accountability to local authorities and create an implied or interpreted right to discretionary use, without reference to leaders' coordination and locally developed common property institutions.

- De facto open access/privatization attempts: Loss of traditional local regulations and inapplicability and lack of enforcement of state regulations has led to situations of no regulation - open access prevails, leading to overuse and degradation of the pastoral resources. At the same time there are attempts by powerful leaders to step into this power vacuum and privatize pastoral areas, whether by right or might (i.e., land grabbing).

- Reduced mobility: Due to the loss of large areas of seasonal pasture, which have been flooded or starved of water by dams, cordoned off as protected areas or privatized, pastoralists themselves are no longer able to be as mobile as is their custom. This contributes additional pressure, as they depend more and more on those pastures that are still available to them.

These various elements are not isolated from, but instead reinforced by each other, in positive feedback loops of fit and misfit: Dismantling local institutions and opening access to the pastoral areas, whether through unenforced or poorly conceptualized state institutions, under constellations of increasing relative prices for pasture and cattle, in turn leads to open access use and/or further privatization. Under such constellations, use of pasture is intensified, be it because control is lacking, because the users interested in privatization are willing to open areas for market purposes or because new users, who are willing and able to pay for access, enter into the area, which is then used without traditional regulation.

If we now switch to the only case in our comparison that shows an institutional fit during the time of our field research, we see similarities between this case, in the Rufiji area in Tanzania, and the settings of precolonial institutional fit. In line with most of Ostrom's design principles (including clear boundaries, cost-benefit-balance, collective choice arrangements, monitoring, graduated sanctioning, conflict resolution mechanisms, the right to organize, as well as nested enterprises) (Ostrom 1990), we see these principles in place in the case of Rufiji pasture use. However, we argue that not all principles or factors have the same importance in the Rufiji case and therefore propose a weighted rating or prioritization of factors.

First, the basis for the successful institutional setting in the Rufiji case, as well as in the other cases before the advent of colonial and postcolonial institutional misfit, appears to lie in the presence of a mutual economic interest between the different actor groups, who realize that they gain from joint management. In the Rufiji case, the key aspect is that leaders of both groups saw mutual benefits in having pastures used by the Barabaig. For the Barabaig the usefulness is obvious, for the Warufiji the usefulness is based on perceived benefits from the availability of milk and meat, which are otherwise expensive in the area. The cooperation happened after some first rather negative initial reactions to the presence of the Barabaig. However, this economic benefit seems to have been crucial as a trigger for reaching an agreement. Shared use of pastures is of value to both groups and the rules for sharing 
Table 2. Major findings of the comparison of institutional fit and misfit in four pastoral commons in African Floodplains.

\begin{tabular}{|c|c|c|c|}
\hline Case study & Element of precolonial fit institutions & Elements of postcolonial misfit & Elements of postcolonial fit \\
\hline $\begin{array}{l}\text { Kafue Flats, } \\
\text { Zambia }\end{array}$ & $\begin{array}{l}\text { - leaders regulate access, } \\
\text { - dynamic adaptation to floods, } \\
\text { - low transaction costs, win win solutions } \\
\text { for user groups (reciprocal access) } \\
\text { - embedded in religious institutions }\end{array}$ & $\begin{array}{l}\text {-loss of local institutions and ownership by } \\
\text { state control (laws) } \\
\text {-centralized but de facto open access } \\
\text { not flood adapted } \\
\text {-reduction of pasture (dams) } \\
\text {-high relative prices for cattle } \\
\text { - resource conflicts }\end{array}$ & None present \\
\hline $\begin{array}{l}\text { Waza Logone, } \\
\text { Cameroon }\end{array}$ & $\begin{array}{l}\text {-institutions lead by leaders, coordination } \\
\text { between different groups } \\
\text { - adaptation to flooding pattern, mutual } \\
\text { interest and win win solution for nomads } \\
\text { and fishermen (trade) } \\
\text { - institutions embedded in religious } \\
\text { institutions }\end{array}$ & $\begin{array}{l}\text {-loss of local institutions and state } \\
\text { governance } \\
\text { Tax payments and de facto open access } \\
\text {-increase in relative prices and attraction of } \\
\text { area } \\
\text {-reduction of area (dams and PAs) } \\
\text { High relative prices } \\
\text { Resource conflicts }\end{array}$ & $\begin{array}{l}\text { Return of flood (IUCN-Project), however } \\
\text { with too little institutional incentives }\end{array}$ \\
\hline Pangani, Tanzania & $\begin{array}{l}\text { - Separation of use and institutional setting } \\
\text { for use of pasture and mountains } \\
\text { - Within groups clear institutional } \\
\text { structures } \\
\text { adapted seasonally mobility patterns } \\
\text { - institutions embedded in religious } \\
\text { institutions }\end{array}$ & $\begin{array}{l}\text { - Merging of groups while cross cutting } \\
\text { ecosystems for state management } \\
\text { - Loss of local institutions and reduction of } \\
\text { mobility } \\
\text { - State property and reduction of land } \\
\text { (settlers and PAs) } \\
\text { - Open access (ujamaa) } \\
\text { - High relative prices and resource conflicts }\end{array}$ & $\begin{array}{l}\text { None for pasture, some collective action } \\
\text { for new water regulations } \\
\text { Collective land act but no coordination } \\
\text { between ethnic and economic groups }\end{array}$ \\
\hline Rufiji, Tanzania & $\begin{array}{l}\text { - Local institutions by WaRufiji based on } \\
\text { leaders } \\
\text { - Adapted to seasonal structure } \\
\text { - No use of pasture } \\
\text { - institutions embedded in religious } \\
\text { institutions }\end{array}$ & $\begin{array}{l}\text { - State control and dismantling many } \\
\text { tradition rules BUT not affecting pasture }\end{array}$ & $\begin{array}{l}\text { - Mutual interests of two groups and } \\
\text { economic benefits (Trade of goods and } \\
\text { services between groups) } \\
\text { - Village authority tolerated by state: } \\
\text { possibility for local people of crafting new } \\
\text { institutions } \\
\text { - Leaders reducing transaction costs and } \\
\text { trust building }\end{array}$ \\
\hline
\end{tabular}

have been adapted to the specific characteristics of ecosystem (floods) in which that sharing is taking place.

A second key to the fit scenario is the fact that local actors are able to decide themselves on how to organize resource use. This is the case in precolonial settings as well as in the Rufiji case. In Rufiji case, as compared to the Pangani area, the pasture areas are within the village boundaries and local actors are able to decide the rules of use on their own, based on Tanzania's village land act. This is the basis for their entitlement to enter into negotiation with the Barabaig, with the possibility to devise new rules.

A third factor is that key actors in the fit scenarios engage in what in game theory is called an iterated prisoners dilemma, which seems to enable cooperation: Leaders take up the transaction costs of negotiation and are successful in establishing mutual trust from repeated interaction and to establish control over expected outcomes, which renders long term cooperation possible. Such long term cooperation is the key to the precolonial fit, which is in line with Ostrom's design principles: In the case of collaboration between the Warufiji and the Barabaig, common property regimes have been crafted that show all aspects of these design principles, including clear but at the same time flexible boundaries (for floodplain areas), membership, monitoring and sanctioning, conflict resolution mechanisms, and nested enterprises (integrated with state regulations and with a local authority with autonomy of decision, that is backed by the state).

The fourth and final factor we observed is that conditions for achieving fit appear most promising when groups and their actors perceive the starting point for the contact situation in such a manner that all sides are understood to be interested in reaching an agreement that shows some benefits - this need not necessarily reflect expectations of a complete win-win scenario but it seems crucial that there is, at least, not a compete win-lose situation on offer.

\section{CONCLUSIONS}

In closing, we wish to consider how these empirical insights can bring us further in elaborating and applying the concept of institutional fit. We follow Young (2008) closely, insofar as we conclude that a positive fit to social-environmental systems has to be adapted to key elements of the cultural landscape and ecosystem in place (such as flooding patterns, influenced by human use, and specific and varying quality of a given pasture) and also to the political landscape. In order 
to outline legitimate demands for ownership the specific characteristics of the cultural landscape and ecosystem must be taken into account. Understanding that there is coevolution of natural conditions and the institutionally coordinated transformation of nature through anthropogenic contributions to ecosystems also seems to be critical. This means, for example, that, without pastoralists' use, continued pastoralist use of the landscape is endangered. Adaptation to the political landscape then includes the need for recognition by different groups of actors that there is a mutual benefit to be gained from cooperation.

We would argue that this has less to do with a pure notion of sustainability and more to do with strategic action that is politically and livelihood oriented. We have observed, in the Rufiji River Floodplain, that, given a setting in which they are able to organize, pastoralists, and settled peoples can establish new creative solutions that are surprisingly similar to the precolonial fit. Here reliance upon leaders who are legitimate, according to local criteria, and have a specific local reputation, helps a great deal to reduce the transaction costs of organization and institution crafting.

However, this brings out the importance of power as a determining factor in these situations. Various different types of power - conceptualized as bargaining power in terms of land use claims - are wielded here by various different actors: some local, some not; some exclusively market based, some not. This bargaining power can be understood to change according to the interplay between external factors, such as relative price changes and internal aspects, such as ideology, which legitimizes actions and the way institutions are transformed (Ensminger 1992, Haller 2010c). As relative prices change, due to external pressures (market, environmental, technological, demographic), the bargaining power of different actors and their potential to influence the decisions of other groups also changes. This process influences institutional fit because some actors, particularly those concerned with subsistence, as opposed to purely market oriented production, are more interested in maintaining good relations with other resource users and with the ecosystem itself.

In the cases we studied, it seems that decisions regarding whether a mutually beneficial (and here we include the ecosystem as a beneficiary) distribution of access to, and use of the common-pool resources can be developed depends in large part on which types of actors have the most bargaining power. Where local bargaining power is high and wellcoordinated among local actors, that there are mechanisms in place to stop external capture of or by elites, the likelihood that the result will be more close to what we might term 'sustainable use' is much higher. In all the areas that we have studied, ecological data indicate major negative changes have arisen after major loss of local institutions. Paradoxically, this is usually following increased state regulation, which leads to de facto open access situations and privatizations (Haller $2010 c$ ). As suggested by the Rufiji case, it would seem that, where people are focused on local livelihoods and are able to perceive the locally negative side of positive feedback loops of overuse - intensification of resource use, leading to instability of the ecosystem, leading to further intensification - new institutional fit can emerge, if local groups are free to craft new rules and given sufficient autonomy to enforce them. Again, bringing in thinking from political ecology, we may argue that leaders who are part of the crafting process have to be legitimate and accountable, at least to a certain degree (see Ribot 2004). We would not argue that this legitimacy and accountability have to be perfectly in keeping with conventional political theory, which itself contains a good deal of colonial intellectual baggage, but wish, instead, to draw attention to the importance of legitimacy and accountability for coordinating shared use of floodplain resources, which requires that some community authority is correcting excessively strong individualistic behaviors.

In closing, we propose that there are at least two lessons to be learned when explicit attention is given to the complex role of the cultural landscape and the ecosystem as factors influencing the fitness landscape for institutions: from an ecosystem approach, we learn to keep in mind how fast feedback loops can occur and how these may, or may not be perceived by the different actors; from an institutional perspective we learn that, from a diversity of possible institutional traits - understood here as culturally devised possibilities for strategies and institutions - the ones selected, which are defined by the standpoint of actors with most bargaining power, may serve either to reinforce the presence of a productively balanced cultural landscape cum ecosystem, to reconfigure and adapt it to changing internal and external conditions or, indeed, to destroy it.

The importance of level bargaining power, based on ensuring the existence of mutual benefits and ensuring high bargaining power among local subsistence groups, who are living directly from and with these cultural landscape cum ecosystems, seems to us to be a crucial topic for further studies. Here we propose that, in order to develop a revised version of the concept of institutional fit, that more accurately reflects the fit problems faced by the floodplain communities we have studied, the history of land use negotiation processes, including questions of how and by whom resources and resource rights are perceived and achieved, must be taken into account. This should be done especially by paying attention to local perceptions of power constellations and institution building processes and to the way in which bargaining power, ideological justification (including traditional religious rules), and external pressures (such as colonialism and state intervention in local governance) are related to the shaping and reshaping of cultural landscapes and, in as much, the shaping of the ecosystems within which they are embedded. 
Responses to this article can be read online at: http://www.ecologyandsociety.org/issues/responses. $\mathrm{php} / 5510$

\section{Acknowledgments:}

The authors acknowledge support from University of Zurich and Bern, Switzerland. T. Haller's research was funded by a grant from the Swiss National Science foundation, the other authors were part of the research programme of the National Center of Competence in Research of the Swiss National Science Foundation called NCCR North South. Mitigating Syndromes of Global Change, University of Bern, Switzerland, IP 6 (Institutional Change and Livelihood Strategies). The NCCR North South also funded the research of G. Fokou, G. Mbeyale and P. Meroka.

\section{LITERATURE CITED}

Acreman, M. C., and G. E. Hollis, editors. 1996. Water Management and Wetlands in Sub-Saharan Africa. IUCN, Gland Switzerland.

Agrawal, A. 2003. Sustainable governance of common pool resources: context, methods and policy. Annual Review of Anthropology 32: 243-262. $\quad$ http://dx.doi.org/10.1146/ annurev.anthro.32.061002.093112

Bagachwa, M. S. D. and F. Limbu. 1995. Policy Reform and the Environment in Tanzania, Dar es Salaam. Dar es Salaam. University Press.

Beeler, S and K. Frei. 2010. Between water spritis and market forces: institutional change in the Niger Delta fisheries among the Somono and the Bozo fishermen of Wandiaka and Daga. Womina (Mali). Pages 77-120 in T. Haller, editor. Disputing the Floodplains: Institutional Change and the Politics of Resource Management in African Floodplains. Brill: Leiden.

Becker, D. C. and E. Ostrom. 1995. Human ecology and resource sustainability: the importance of institutional diversity. Annual Review Ecology and Systematics. 26: 113-33. http://dx.doi.org/10.1146/annurev.es.26.110195.000553

Berkes, F., editor. 1989. Common Property Resources: Ecological and Community-based Sustainable Development. London: Belhaven Press.

Borras, S. M., Jr., and J. Franco. 2010. Towards a Broader View of the Politics of Global Land Grab: Rethinking Land Issues, Reframing Resistance. ICAS Working Paper Series No. 001.
Brockington, D. and K. Homewood. 2001. Degradation debates and data deficiencies: The Mkomazi Game Reserve, Tanzania. Africa 71(3): 449-479.

Brockington, D. 2002. Fortress Conservation: the Preservation of the Mkomazi Game Reserve, Tanzania. African Issues. London, James Currey.

Brown, T. 2005. Contestation, confusion and corruption: market-based land reform in Zambia. Pages 79-102 in S. Evers, M. Spierenburg, and H. Wels, editors. Competing Jurisdictions: Settling Land Disputes in Africa. Leiden: Brill.

Bromley, D. and W. Cernea. 1989. The Management of Common Property Resources: Some Conceptual and Operational Fallacies. New York: World Bank.

Cotula L., S. Vermeulen, R. Leonard, and J. Keeley. 2009. Land grab or development opportunity? Agricultural investment and international land deals in Africa. FAO, IIED and IFAD. Rome, Italy.

Drijver, C. A. and M. Marchand. 1985. Taming the Floods: Environmental Aspects of Floodplain Development in Africa. Centre for Environmental Studies. Leiden University.

Ellenbroek, G. A. 1987. Ecology and productivity of an African wetland system. The Kafue Flats, Zambia. Geobotany 9. Leiden: Kluwer: Dordrecht, The Netherlands. http://dx.doi. org/10.1007/978-94-009-4051-2

Ensminger, J. 1992. Making a market. The Institutional Transformation of an African Society. Cambridge: Cambridge University Press.

Ensminger, J. 1998. Anthropology and the new institutionalism. Journal of Institutional and Theoretical Economics 154: 774-789.

Farrell, K. 2007. Living with living systems. Co-evolution with values and valuation. International Journal of Sustainable Development \& World Ecology 14: 14-26 http:// dx.doi.org/10.1080/13504500709469704

Fokou, G. 2008. Gestion communautaire des ressources naturelles et relations de pouvoir. Etude anthropologique des changements institutionnels dans les Plaines du Logone et du Lac Tchad. Ph. D diss. Yaounde, Cameroon: University of Yaounde.

Fokou, G. 2010. Tax payments, democracy and rent seeking administrators: common-pool resource management, power relations and conflicts among the Kotoko, Musgum, Fulbe and Arab Choa in the Waza Logone floodplain (Cameroon). Pages 
121-169 in T. Haller, editor. Disputing the Floodplains: Institutional Change and the Politics of Resource Management in African Floodplains. Brill: Leiden. http://dx. doi.org/10.1163/ej.9789004185326.i-454.33

Haller, T. 2007a. Understanding institutions and their links to resource management from the perspective of new institutionalism. NCCR North-South Dialogue 2. Bern: Switzerland: NCCR North-South.

Haller, T. 2007b. Is there a culture of sustainability? What social and cultural anthropology has to offer 15 years after Rio. Pages 329-356 in P. Burger and R. Kaufmann-Hayoz, editors. 15 Jahre nach Rio - Der Nachhaltigkeitsdiskurs in den Geistes- und Sozialwissenschaften: Perspektiven - Leistungen Defizite. Schweizerische Akademie der Geistes und Sozialwissenschaften Bern, Switzerland.

Haller, T. 2010a. Common-pool resources, legal pluralism and governance from a new institutionalist perspective: lessons from the African Floodplain Wetlands Research Project (AFWeP). Pages 137-178 in I. Eguavoen and W. Laube, editors. Negotiating Local Governance. Natural Resources Management at the Interface of Communities and the State. ZEF Development Studies. Munich/London/New York: Lit. Publishers.

Haller, T. 2010b. Institutional change, power and conflicts in the management of common pool resources in African floodplain ecosystems. Pages 1-76. in Haller, T. editor. Disputing the Floodplains: Institutional Change and the Politics of Resource Management in African Floodplains. Brill: Leiden.

Haller, T., editor. 2010c. Disputing the Floodplains: Institutional Change and the Politics of Resource Management in African Floodplains. Leiden, The Netherlands: Brill. http://dx.doi.org/10.1163/ej.9789004185326. i-454

Haller, T. 2010d. Between open access, privatisation and collective action: a comparative analysis of institutional change governing use of common pool resources in African floodplains. Pages 413-444. in T. Haller, editor. Disputing the Floodplains: Institutional Change and the Politics of Resource Management in African Floodplains. Brill: Leiden. http://dx. doi.org/10.1163/ej.9789004185326.i-454.112

Haller, T. 2013. The Contested Floodplain. Institutional Change of the Commons in the Kafue Flats, Zambia. Lexington Books/Rowman and Littlefield Publishing Group. Lanham.

Haller, T., and M. Galvin. 2008. Introduction: the problem of participatory conservation. Pages 13-34 in M. Galvin and T. Haller, editors. People, protected areas and global change: participatory conservation in Latin America, Africa, Asia and Europe. Perspectives of the Swiss National Centre of
Competence in Research (NCCR) North-South, University of Bern, Geographica Bernensia, 3: Bern: Switzerland.

Haller, T., M. Galvin, P. Meroka, J. Alca, and A. Alvarez. 2008. Who gains from community conservation? Intended and unintended costs and benefits of participative approaches in Peru and Tanzania. " Journal of Environment and Development 17(2): 118-144. http://dx.doi.org/10.1177/107$\underline{0496508316853}$

Haller, T., and S. Merten. 2008. "We are Zambians - don't tell us how to fish!" Institutional change, power relations and conflicts in the Kafue Flats fisheries in Zambia. Human Ecology 36(5): 699-715. http://dx.doi.org/10.1007/s10745-008-9191-4

Haller, T., and S. Merten. 2010. "We had cattle and did not fish and hunt anyhow!" Institutional change and contested commons in the Kafue Flats floodplain (Zambia). Pages 301-360 in T. Haller, editor. Disputing the Floodplains: Institutional Change and the Politics of Resource Management in African Floodplains. Brill: Leiden. http://dx. doi.org/10.1163/ej.9789004185326.i-454.86

Hardin, G. 1968. The tragedy of the commons. Science 162: 1243-48. http://dx.doi.org/10.1080/19390450903037302

Homewood, K. 2008. Ecology of African Pastoralist Societies. Oxford: James Currey.

Hughes R. H., and J. S. Hughes, editors. 1992. A Directory of African Wetlands. Gland, IUCN.

McCabe, T. 1990. Turkana pastoralism: a case against the tragedy of the commons. Human Ecology 18(1): 81-103. http://dx.doi.org/10.1007/BF00889073

Mbeyale, G. 2008. The impact of institutional changes and the management of common-pool resources in Pangani River Basin. A case of same district, Tanzania. Ph. D Thesis, University of Dar es Salaam: Dar es Salaam, Tanzania.

Mbeyale, G. 2010. From integrated slope management to fragmented use: common-pool resources institutional change and conflicts in the Pangani River Basin of same district (Tanzania), in Haller, T., editor. Disputing the Floodplains: Institutional Change and the Politics of Resource Management in African Floodplains. Brill: Leiden: pp. 195-244. http://dx.doi.org/10.1163/ej.9789004185326.i-454.60

Mbeyale, G., and A. Songorwa. 2008. Conservation for whose benefit? Challenges and opportunities for management of Mkomazi Game Reserve, Tanzania. Pages 221-251 in M. Galvin and T. Haller, editors. People, protected areas and global change: participatory conservation in Latin America, Africa, Asia and Europe. Perspectives of the Swiss National Centre of Competence in Research (NCCR) North-South, 
University of Bern, Geographica Bernensia, 3. Bern: Switzerland: NCCR North-South.

McKean, M. 2000. Common Property: what it is, what it is good for, and what makes it work? In C. Gibson, M. McKean, and E. Ostrom, editors. People and forests: communities, institutions, and governance. Cambridge: MIT Press.

Meroka, P. 2006. Common-Pool Resource Management and Conflict Resolution in Rufiji Floodplain, Tanzania. Ph. D Thesis. University of Zurich: Zurich, Switzerland

Meroka,P. 2010. Ujamaa policies, open access and differential collective action: common-pool resource management, institutional change and conflicts in the Rufiji floodplain (Tanzania), in Haller, T., editor. Disputing the Floodplains: Institutional Change and the Politics of Resource Management in African Floodplains. Brill: Leiden: pp. 245-300. http://dx.doi.org/10.1163/ej.9789004185326.i-454.73

Meroka, P., and T. Haller 2008. Government wildlife, unfulfilled promises and business: lessons from participatory conservation in the Selous Game Reserve, Tanzania. Pages 177-219 in M. Galvin and T. Haller, editors. People, protected areas and global change: participatory conservation in Latin America, Africa, Asia and Europe. Perspectives of the Swiss National Centre of Competence in Research (NCCR) NorthSouth, University of Bern. Geographica Bernensia, 3. Bern: Switzerland.

Moritz, M., P. Scholte, and S. Kari. 2002. The demise of the nomadic contract: arrangement and rangelands under pressure in the far north of Cameroon. Nomadic Peoples 6(1): 127- 146. http://dx.doi.org/10.3167/082279402782311013

Neumann, R. P. 1998. Imposing wilderness. Struggles over livelihood and nature preservation in Africa. Berkley: University of California Press.

North, D. 1990. Institutions, institutional change and economic performance. Cambridge: Cambridge University Press. http://dx.doi.org/10.1017/CBO9780511808678

Ostrom, E. 1990. Governing the commons. The evolution of institutions for collective action. Cambridge: Cambridge University Press. http://dx.doi.org/10.1017/CBO9780511807763

Ostrom, E. 2005. Understanding institutional diversity. Princeton and Oxford, Princeton University Press.

Ostrom, E., T. Dietz, N. Dolsak, P. C. Stern, S. Stonich, and U. E. Weber. 2002. The drama of the commons. National Research Council, Washington D. C., USA: National Academy Press.

Platteau, J-P. 2000. Institutions, Social Norms, and Economic Development. Amsterdam: Harwood Academic Publishers.
Ribot, J., C. 2004. Waiting for Democracy: The politics of choice in natural resource decentralization. Washington DC: World Resource Institute.

Sahlins, M. 1972. Stone Age Economics. Aldine. Chicago, U. S.A.

Saum. R. 2010. Promise and reality of community based natural resource management in Botswana: common-pool resource use and institutional change in Ikoga, Okovango Delta (Panhandle). Pages 361-412 in Haller, T., editor. Disputing the Floodplains: Institutional Change and the Politics of Resource Management in African Floodplains.. Brill: Leiden. http://dx.doi.org/10.1163/ej.9789004185326. i-454.99

Spear, T. 1997. Mountain Farmers. Oxford: James Currey.

Williamson, O. E. 1975. Markets and Hierarchies, Analysis and Antitrust Implications: A Study in the Economics of Internal Organization. New York: Free Press.

Woodhouse, P., H. Bernstein, and D. Hulme, editors. 2000. African Enclosures. The Social Dynamics of Wetlands in Drylands. Trenton Publishers. Asmara, Eritrea. Africa World Press. http://dx.doi.org/10.1016/S0305-750X(03)00140-2

Young, O. R. 2008. The architecture of global environmental governance: to bear on policy. Global Environmental Politics 8(1): 14-32. http://dx.doi.org/10.1162/glep.2008.8.1.14

Zimmerer, K. S. and T. J. Bassett, editors. 2003. Political Ecology. New York, London: Guilford Press. 